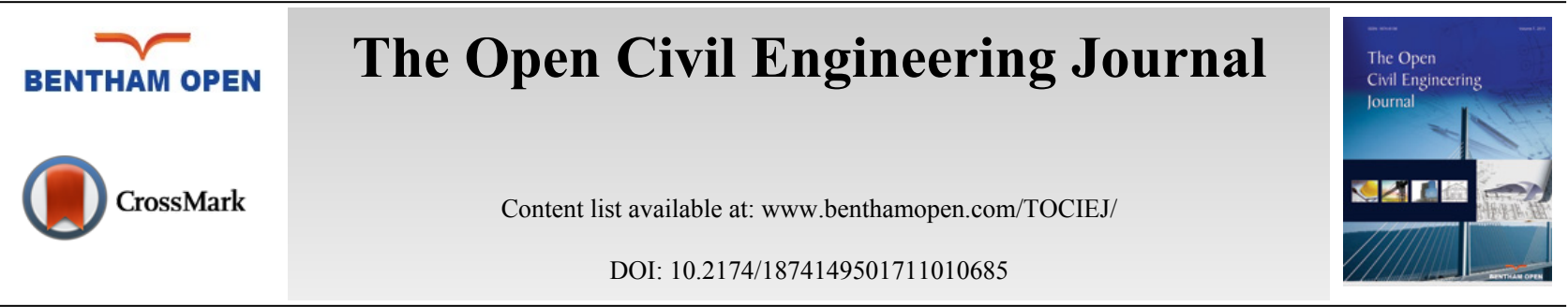

RESEARCH ARTICLE

\title{
Bond Behaviors Between Full-Recycled-Aggregate Concrete and Deformed Steel-Bar
}

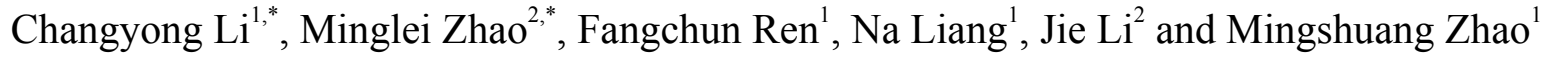 \\ ${ }^{1}$ Henan Province International United Lab of Eco-building Materials and Engineering, School of Civil Engineering and \\ Communication, North China University of Water Resources and Electric Power, No. 136 Jinshui East Road, 450046 \\ Zhengzhou, China \\ ${ }^{2}$ School of Engineering, RMIT University, Melbourne, VIC 3053, Australia
}

Received: January 03, 2017

Revised: July 05,2017

Accepted: July 12, 2017

\begin{abstract}
:
Introduction:

Full-recycled-aggregate concrete (aRAC) is a new concrete reusing $100 \%$ fine and coarse recycled aggregates produced from waste concrete of demolished concrete structures. As there is a lack of studies on the bond behavior between steel bar and aRAC, findings of this study are of significance for the structural application of aRAC.
\end{abstract}

\section{Method:}

This paper presents the pull-out test results of 24 groups aRAC specimens with deformed steel bar, and discusses the effects of aRAC strength, bond length and lateral constructional stirrups on the bond behavior between deformed steel bar and aRAC.

\section{Results and Conclusion:}

The bond stress and slip at key points of bond-slip curve are analyzed in relation to the tensile strength of aRAC and the bond length of steel bar. The bond-slip relationship between deformed steel bar and aRAC is proposed based on the test and analysis of this study.

Keywords: Full-recycled-aggregate concrete, Deformed steel bar, Bond behavior, Bond-slip curve, Pull-out test, RCA.

\section{INTRODUCTION}

With the rapid urbanization development and cities' improvement in China, construction waste has piled up like a mountain, which should be dealt with urgently. An approach is to crush the waste concrete from demolished concrete structures to obtain recycled concrete aggregate (RCA) for the production of a new concrete, commonly known as recycled aggregate concrete (RAC) [1 - 4]. In fact, study and application of RAC have drawn global attention in accordance with the green and sustainable construction $[5-10]$.

According to current studies, the special characteristics of coarse RCA differ from naturnal aggregate such as rough surface with certain amount of old cement mortar attached, low density, and high and quick water absorption, having certain effects on the properties of RAC. Commonly, the RAC is produced by the simple method of partially replacing natural coarse aggregate with coarse RCA, where the content of coarse RCA is always considered as an important factor to qualify the properties of RAC. Generally, with the increasing content of coarse RCA, RAC with similar mix proportion decreases in compressive strength, tensile strength and modulus of elasticity [3, 4, 8 - 11]. However, from

\footnotetext{
* Address correspondence to authors at the School of Civil Engineering and Communication, North China University of Water Resources and Electric Power, No. 136 Jinshui East Road, 450046 Zhengzhou, China; Fax: +8637169127373; E-mail: 5489953@99.com; School of Engineering, RMIT University, Melbourne, VIC 3053, Australia; E-mail: coffeyha@aliyun.com
} 
the perspective of concrete technology, in terms of achieving the same target workability and compressive strength, the mix proportion of RAC should adjust with different hybrid RCA and natural aggregate [12 - 14]. With the appropriate mix design, reasonable mineral admixtures, pre-wetting RCA and proper mixing process [15 - 19], the performance of RAC can be equal or exceed that of ordinary concrete referenced. Meanwhile, compared with natural sand, fine RCA has very different characteristics such as angular and irregular particles, high mortar contents, non-uniform morphology for containing a mixture of $\mathrm{C}-\mathrm{S}-\mathrm{H}$ and $\mathrm{CH}$ formations, and low density and high water absorption as result of the heterogeneous nature of natural aggregate and cement paste. These characteristics of fine RCA lead to the much complexity and variations in mix proportion, workability, mechanical properties and durability of RAC [3, 4, 20, 21]. Based on the reviews of current researches, the production of full-recycled-aggregate concrete (aRAC) made of $100 \%$ coarse and fine recycled aggregates is a new approach to improve the efficiency of reusing all recycled products of waste concrete $[22,23]$.

As the key issue for a reliable use of aRAC in reinforced concrete structures, bond behaviors between steel bar and aRAC should be explained. By conducting the pull-out test, Kim and Yun [24] studied the effects of fine RCA content in the whole fine aggregate and water absorption of fine RCA on the bond strength between deformed steel bar and RAC with natural coarse aggregate. They concluded that when the compressive strength of different RAC was almost equal, bond strength did not seem to be affected by the fine RCA content at least for up to $60 \%$ fine aggregate when the fine RCA was lower in water-absorption. However, the bond strength showed a clear decrease with the increase of water-absorption of fine RCA. By conducting the beam-end test, Butler et al. [25] studied the bond strength between deformed steel bar and aRAC with similar compressive strength, and made the conclusion that bond strength had a strong negative relationship with the crushing value of coarse RCA. Hu et al. [26] found that the bond strength between deformed steel bar and RAC with 100\% coarse RCA decreased with the increasing replacement content of fine RCA to whole fine aggregate.

In addition, the following studies on bond behaviors between steel bar and RAC made of coarse RCA are also valuable. In these studies, several main factors were examined such as the $0-100 \%$ coarse RCA, the $3 d-25 d$ bond length of steel bar (where $d$ is the diameter of steel bar), the $8 \mathrm{~mm}-25 \mathrm{~mm}$ diameter of steel bar, and the type of steel bar as plain and deformed. The pull-out test, beam-end test and beam bond test were applied. Due to the multi-actions on the interface of steel bar and RAC, failures of specimens took place as the pull-out of steel bar [27, 28], splitting of concrete [27 - 32] or yield of steel bar [30,31]. Such multi-actions were affected by the RAC strength, the RAC depth covering steel bar and the bond length and type of steel bar. Similar to those of referenced ordinary concrete, pull-out of steel bar often took place on specimens with plain steel bar, and those with deformed steel bar in condition of relatively low RAC strength and deep covering depth. Splitting of concrete normally appeared on specimens with deformed steel bar, when the RAC strength was high and the covering depth was shallow. Yield of steel bar came up when the bond length of steel bar was long enough. The difference of bond stress along steel bar was measured by the continuous strain gauges pasted along the internally axial groove of steel bars [28 - 30], which explained the mechanism of the decrease of the bond strength with the increasing bond length [26, 28]. As present in referenced ordinary concrete, similar effects of the type and diameter of steel bar existed on the bond behaviors between steel bar and RAC. Bond strength of deformed steel bar is 2 4 times higher than that of plain steel bar, and decreases with the increasing diameter of steel bar [28, 30, 31, 33 - 36]. As reported [27 - 30, 33, 34], the bond strength between deformed steel bar and RAC decreased with the content of coarse RCA. In fact, it was a superficial phenomenon, as that the direct replacement of partial natural coarse aggregate by coarse RCA resulted in the reduction of RAC strength. If the bond strength was normalized as the ratio to the compressive strength, square root of compressive strength or tensile strength of RAC, it was only slightly affected by the content of RCA and no less than that of referenced ordinary concrete [28, 33 - 37], even increased with the increasing content of RCA [32, 33, 35]. Meanwhile, when the mix proportion of RAC was adjusted properly to get an equal compressive strength with referenced ordinary concrete, the bond behavior was similar and the bond strength was not influenced by the content of RCA [38 - 40], even a higher normalized bond strength reached with the increased content of RCA [26, 31]. From a general view, the bond strength between steel bar and RAC was reliable compared with the referenced ordinary concrete under the same conditions.

However, Butler et al. [41] reported that by using beam-end test, when replacing 100\% natural coarse aggregate with coarse RCA while maintaining similar compressive strengths of RAC, bond strength decreased linearly with the decrease of coarse RCA strength. For the bond-splitting cracks occurred mainly through the coarse RCA particles. Besides, when the pull-out failure of steel bar took place, the bond strength and the normalized bond strength to the square root of compressive strength of RAC declined with the increased content of RCA [42], and had a reduction with 
the enlarging of the particle size of RCA especially for deformed steel bar placed horizontally [43].

Given the above, in this paper, we are specifically interested to study the bond behavior between deformed steel bar and aRAC. Twenty-four groups of specimens were tested by using the pull-out test method, considering the effects of aRAC strength, bond length of steel bar, and lateral constructional stirrups. Based on the analysis of test results, formulas are expressed for the bond-slip relationship.

\section{EXPERIMENTAL PROCEDURE}

\subsection{Raw Materials}

Grade 42.5 and 52.5 ordinary silicate cements were adopted. Table 1 lists their physical and mechanical properties.

Table 1. Physical and mechanical properties of cement.

\begin{tabular}{|c|c|c|c|c|c|c|c|c|}
\hline \multirow{2}{*}{ Grade } & \multirow{2}{*}{$\begin{array}{c}\text { Fineness } \\
\mathbf{( \% )}\end{array}$} & $\begin{array}{c}\text { Consistency } \\
\mathbf{( \% )}\end{array}$ & \multicolumn{2}{|c|}{ Setting time (min) } & \multicolumn{2}{c|}{ Compressive strength (MPa) } & \multicolumn{2}{|c|}{ Flexural strength (MPa) } \\
\cline { 5 - 9 } & & Initial & Final & 3 days & 28 days & 3 days & 28 days \\
\hline P.O 42.5 & 4.7 & 28.5 & 142 & 229 & 26.1 & 49.4 & 4.97 & 8.64 \\
\hline P.O 52.5 & 2.0 & 28.9 & 145 & 233 & 36.3 & 57.7 & 6.45 & 8.74 \\
\hline
\end{tabular}

Coarse RCA mixed in proportion of 4:3:3 by the series in size of $5-10 \mathrm{~mm}, 10-15 \mathrm{~mm}$ and $15-20 \mathrm{~mm}$. It was crushed from waste reinforced concrete beams tested 5 years ago in NCWU lab, and graded by sieving in accordance with China Standard GB/T 25177 [1]. Table 2 presents the physical and mechanical properties of coarse aRAC.

Table 2. Physical and mechanical properties of coarse RCA.

\begin{tabular}{|c|c|c|c|c|c|c|c|}
\hline $\begin{array}{c}\text { Particle size } \\
(\mathbf{m m})\end{array}$ & $\begin{array}{c}\text { Apparent density } \\
\left(\mathbf{k g} / \mathbf{m}^{\mathbf{3}}\right)\end{array}$ & $\begin{array}{c}\text { Pile-up density } \\
\left(\mathbf{k g} / \mathbf{m}^{\mathbf{3}}\right)\end{array}$ & $\begin{array}{c}\mathbf{2 4} \text { h water absorption } \\
\mathbf{( \% )}\end{array}$ & $\begin{array}{c}\text { Content of needle } \\
\text { pieces } \mathbf{( \% )}\end{array}$ & $\begin{array}{c}\text { Mud content } \\
\mathbf{( \% )}\end{array}$ & $\begin{array}{c}\text { Porosity } \\
\mathbf{( \% )}\end{array}$ & $\begin{array}{c}\text { Crushed index } \\
(\mathbf{\%})\end{array}$ \\
\hline $5 \sim 20$ & 2660 & 1410 & 3.7 & 1.4 & 0.4 & 47 & 13.5 \\
\hline
\end{tabular}

Fine RCA was the fine particles of crushed waste concrete in size less than $5 \mathrm{~mm}$, and graded in zone II by sieving in accordance with China Standard GB/T 25176 [2]; the physical properties are listed in Table 3.

Table 3. Physical properties of fine RCA.

\begin{tabular}{|c|c|c|c|c|c|}
\hline Fineness modulus & $\begin{array}{c}\text { Apparent density } \\
\left(\mathbf{k g} / \mathbf{m}^{\mathbf{3}}\right)\end{array}$ & $\begin{array}{c}\text { Pile-up density } \\
\left(\mathbf{k g} / \mathbf{m}^{\mathbf{3}}\right)\end{array}$ & $\begin{array}{c}\text { Close bulk density } \\
\left(\mathbf{k g} / \mathbf{m}^{\mathbf{3}}\right)\end{array}$ & $\begin{array}{c}\mathbf{2 4} \mathbf{~} \text { water absorption } \\
\mathbf{( \% )}\end{array}$ & $\begin{array}{c}\text { Powder content } \\
\mathbf{( \% )}\end{array}$ \\
\hline 3.05 & 2580 & 1170 & 1360 & 9.1 & 6.6 \\
\hline
\end{tabular}

The deformed steel bar was crescent-rib steel bar in $16 \mathrm{~mm}$ diameter. The yield and ultimate tensile strength were $473 \mathrm{MPa}$ and $639 \mathrm{MPa}$ respectively. Stirrups were made of plain steel bar in diameter of $6 \mathrm{~mm}$ and $4 \mathrm{~mm}$.

Others were the tap water and the commercially available high-performance polycarboxylate-type water reducer with a water-reducing rate of about $20 \%$.

\subsection{Mix Proportion of aRAC}

As listed in Table 4, the mix proportion design of aRAC was based on the preliminary study and in accordance with the specification for ordinary concrete [12, 22]. Grade 42.5 cement was used for casting C 30 and C40 aRAC, grade 52.5 cement was used for casting C50 aRAC. The water reducer dosage changed in $0.75 \%-1.0 \%$ in weight of cement to adjust the workability of fresh aRAC. The water demand composed by the dosage of mix water and the additional water. The additional water was determined by the water absorption of RCA and used for pre-wetting RCA. The mix procedure was as follows: the coarse RCA and fine RCA were kept in the mixer, mixed uniformly and pre-wetted for 1 hour by adding the additional water; cement was added and mixed uniformly; mix water and water reducer were added and mixed for $5 \mathrm{~min}$.

Table 4. Mix proportion of aRAC.

\begin{tabular}{|c|c|c|c|c|c|c|c|}
\hline \multirow{2}{*}{ Mixture } & \multirow{2}{*}{$\boldsymbol{m}_{\mathrm{w}} / \boldsymbol{m}_{\mathrm{c}}$} & \multirow{2}{*}{$\begin{array}{c}\text { Sand ratio } \\
\mathbf{( \% )}\end{array}$} & \multirow{2}{*}{$\begin{array}{c}\text { Water } \\
\left(\mathbf{k g} / \mathbf{m}^{\mathbf{3}}\right)\end{array}$} & \multirow{2}{*}{$\begin{array}{c}\text { Cement } \\
\left(\mathbf{k g} / \mathbf{m}^{\mathbf{3}}\right)\end{array}$} & \multicolumn{2}{|c|}{ Aggregate $\left.\mathbf{( k g} / \mathbf{m}^{\mathbf{3}}\right)$} & \multirow{2}{*}{$\begin{array}{c}\text { Additional water } \\
\left(\mathbf{k g} / \mathbf{m}^{\mathbf{3}}\right)\end{array}$} \\
\hline $\mathrm{C} 30$ & 0.40 & 42 & 166 & 415 & 769.2 & 1062.3 & 105.8 \\
\hline $\mathrm{C} 40$ & 0.32 & 42 & 166 & 519 & 731.7 & 1010.4 & 100.6 \\
\hline
\end{tabular}


(Table 4) contd.....

\begin{tabular}{|c|c|c|c|c|c|c|c|}
\hline \multirow{2}{*}{ Mixture } & \multirow{2}{*}{$m_{\mathrm{w}} / m_{\mathrm{c}}$} & \multirow{2}{*}{$\begin{array}{c}\text { Sand ratio } \\
(\%)\end{array}$} & \multirow{2}{*}{$\begin{array}{c}\text { Water } \\
\left(\mathrm{kg} / \mathrm{m}^{3}\right)\end{array}$} & \multirow{2}{*}{$\begin{array}{c}\text { Cement } \\
\left(\mathrm{kg} / \mathrm{m}^{3}\right)\end{array}$} & \multicolumn{2}{|c|}{ Aggregate $\left(\mathrm{kg} / \mathrm{m}^{3}\right)$} & \multirow{2}{*}{$\begin{array}{c}\text { Additional water } \\
\left(\mathrm{kg} / \mathrm{m}^{3}\right)\end{array}$} \\
\hline & & & & & Coarse & Fine & \\
\hline $\mathrm{C} 50$ & 0.35 & 42 & 166 & 474 & 747.8 & 1032.6 & 102.8 \\
\hline
\end{tabular}

\subsection{Design and Preparation of Specimens}

The bond behavior between deformed steel bar and aRAC was experimented by using the central pull-out test method. The bond-part of steel bar was placed in the central part of concrete specimen with the bond-breakers at the ends. The bond-breakers simulated the real condition of steel bar in concrete and eliminated the local compression on loading surface, which were realized by PVC tubes sealed with paraffin. As shown in Fig. (1) and listed in Table 5, the length of bond part $l_{a}=5 d, 8 d, 10 d$ and $12 d$, the section of specimen was $150 \mathrm{~mm} \times 150 \mathrm{~mm}$, the length $l=l_{a}+70$ (here the length of embedded PVC tube was taken as $35 \mathrm{~mm}$ ), the steel bar at loaded end was kept long enough for pull-out purpose. 24 groups of specimens were designed, each group had 3 specimens. As listed in Table 5, half of the groups were designed with constructional stirrups placed at mid of bond part ( $1 \phi 6$ stirrup when $l_{a}=5 d, 8 d ; 2 \phi 4$ stirrups when $\left.l_{a}=10 d, 12 d\right)$ to prevent concrete splitting. The group no. means bond length and strength grade of aRAC, the last " $\mathrm{R} "$ means the specimens with constructional stirrup(s).

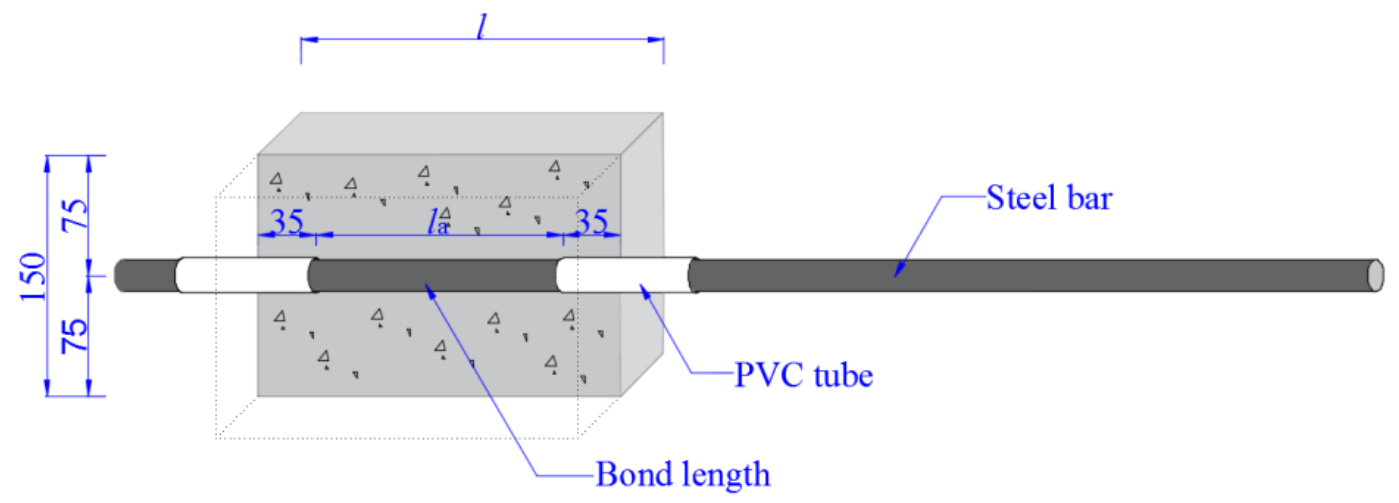

Fig. (1). Dimensions and schematic of specimens.

Table 5. List of information of specimens.

\begin{tabular}{|c|c|c|c|c|c|}
\hline Group no. of specimens without stirrups & Group no. of specimens with stirrup(s) & $\begin{array}{c}\text { Strength grade of aRAC } \\
\text { (MPa) }\end{array}$ & $\begin{array}{c}d \\
(\mathbf{m m})\end{array}$ & $\begin{array}{c}l_{\mathrm{a}} \\
(\mathrm{mm})\end{array}$ & $\begin{array}{l}l \\
(\mathrm{~mm})\end{array}$ \\
\hline $5 \mathrm{dC} 30$ & $5 \mathrm{dC} 30 \mathrm{R}$ & \multirow[t]{4}{*}{30} & \multirow[t]{4}{*}{16} & 80 & 150 \\
\hline $8 \mathrm{dC} 30$ & $8 \mathrm{dC} 30 \mathrm{R}$ & & & 128 & 198 \\
\hline $10 \mathrm{dC} 30$ & 10dC30R & & & 160 & 230 \\
\hline $12 \mathrm{dC} 30$ & $12 \mathrm{dC} 30 \mathrm{R}$ & & & 192 & 262 \\
\hline $5 \mathrm{dC} 40$ & $5 \mathrm{dC} 40 \mathrm{R}$ & \multirow[t]{4}{*}{40} & \multirow[t]{4}{*}{16} & 80 & 150 \\
\hline $8 \mathrm{dC} 40$ & $8 \mathrm{dC} 40 \mathrm{R}$ & & & 128 & 198 \\
\hline $10 \mathrm{dC} 40$ & $10 \mathrm{dC} 40 \mathrm{R}$ & & & 160 & 230 \\
\hline $12 \mathrm{dC} 40$ & $12 \mathrm{dC} 40 \mathrm{R}$ & & & 192 & 262 \\
\hline $5 \mathrm{dC} 50$ & $5 \mathrm{dC} 50 \mathrm{R}$ & \multirow[t]{4}{*}{50} & \multirow[t]{4}{*}{16} & 80 & 150 \\
\hline $8 \mathrm{dC} 50$ & $8 \mathrm{dC} 50 \mathrm{R}$ & & & 128 & 198 \\
\hline $10 \mathrm{dC} 50$ & $10 \mathrm{dC} 50 \mathrm{R}$ & & & 160 & 230 \\
\hline $12 \mathrm{dC} 50$ & $12 \mathrm{dC} 50 \mathrm{R}$ & & & 192 & 262 \\
\hline
\end{tabular}

The preparation and the curing of specimens completed in the lab are shown in Fig. (2). Steel moulds with holes at central of opposite plates ensured the placement of steel bar. The aRAC was put into the moulds and compact on the vibrating platform. After casting for 24 hours, the specimens moved from moulds and placed in the standard curing room for 28 days. To get the real strength of aRAC, cubes in dimension of $150 \mathrm{~mm}$ casted at the same time and cured in the same condition with these specimens. 


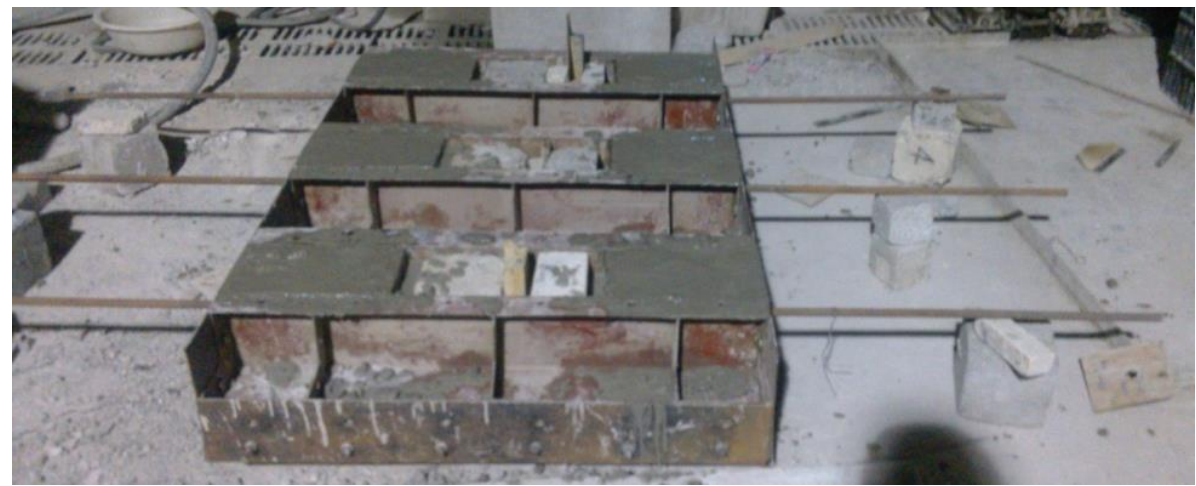

Fig. (2). Preparation of specimens.

\subsection{Test Methods}

As shown in Fig. (3), the loading-end steel bar passed right through the steel plate, steel tube, load meter and hydraulic jack. It was locked at the end of the hydraulic jack. The displacement meter fixed on the steel-bar and protected by the steel tube was to measure the bond-slip of steel bar at the loading-end. The two displacement meters arranged at free-end were to measure the bond-slip of steel bar at free-end from the relative displacement between steel bar and concrete surface. After the specimen and devices fixed together, the displacement meters linked to the strain acquisition system. The initial load on the specimen was to check the reliability of the test system. Then the static loading test started. As specified in China Standard GB 50152 [44], the loading speed changes with different diameter (d) of steel bar; it was taken as $0.05 d^{2}=128 \mathrm{~N} / \mathrm{min}$.

The average bond stress $(\tau)$ is calculated from the tensile load divided by the bond area within the bond length, the maximum value is the bond strength $\left(\tau_{\mathrm{u}}\right)$, that is

$$
\tau=F /\left(\pi d l_{\mathrm{a}}\right)
$$

where, $F$ is the load of pull-out test, $l_{\mathrm{a}}$ is the bond length of steel bar, $d$ is the diameter of steel bar.

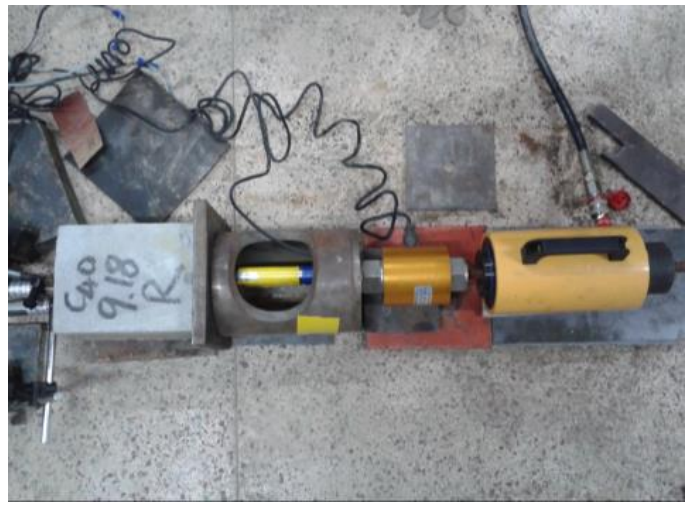

(a)

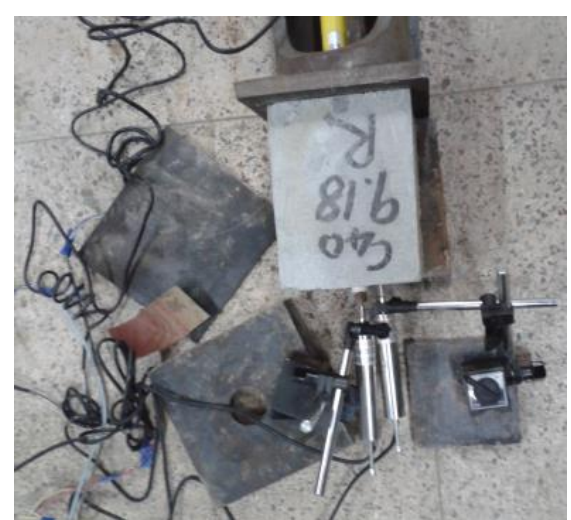

(b)

Fig. (3). Device of pull-out test: (a) entire device arrangement and (b) displacement meters at free-end.

Tests for cubic compressive strength and splitting tensile strength of aRAC were in accordance with the specifications of China Standard GB/T50081 [45].

\section{TEST RESULTS}

In this test, three kinds of failure of specimens took place. They are summarized as follows.

\subsection{Pull-Out Failure and Bond-Slip Curve}

When the bond length of steel bar was $5 d$ or $8 d$, specimens with lateral constructional stirrups could continuously 
bear the pull-out load until the steel bar was pulled out of aRAC. With the sustainable action of pull-out load, the aRAC in front of ribs of deformed steel bar crushed gradually under the shear-compression. The cracks appeared on the surface of specimen, and extended from the loading-end to free-end along the steel bar, as shown in Fig. (4).
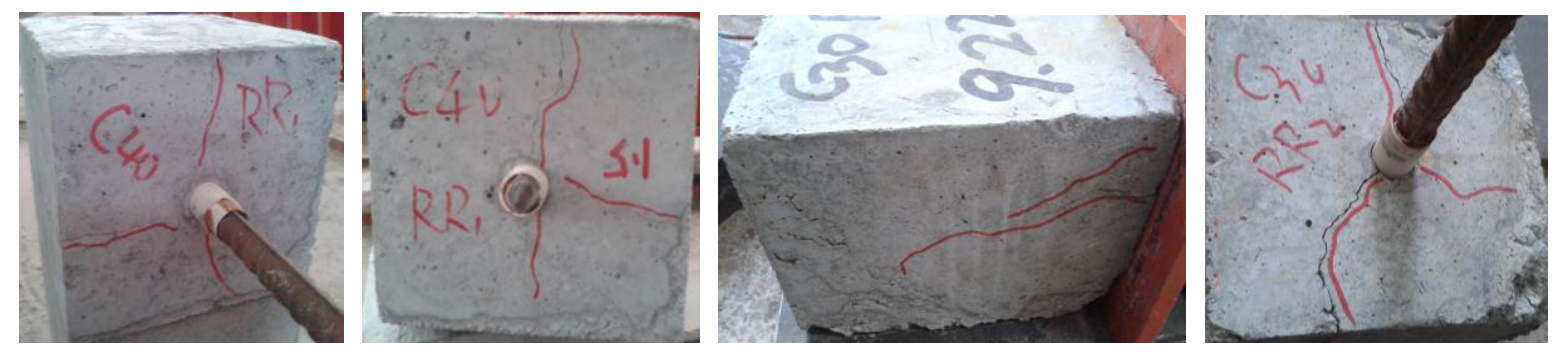

Fig. (4). Steel-bar pull-out failure.

The bond-slip curves of specimens in the pull-out failure are shown in Fig. (5). Four segments are there with the characteristics of micro-slip, slip, internal broken and decline. At the micro-slip segment, the slip increased elastically due to the continuous loss of chemical bond on the interface of steel bar and aRAC. With the increase of slip, the aRAC in front of ribs of steel bar became the main actor bearing pull-out load, the bond stress continuously increased with some nonlinear properties of aRAC under the shear-compression, the nonlinear behavior appeared on bond-slip curve in the slip segment. After that, the slip grew rapidly as the internal breaking of aRAC in front of ribs of steel bar took place continuously, and the non-linear behavior was much obvious until the bond stress reached the maximum value. Due to the confinement of lateral constructional stirrups, the internal cracks of concrete could not extend rapidly, the bond-slip curve came into the decline segment accompanied with the shear fracture and compressive break of aRAC along the steel bar. Meanwhile, as the slip of steel bar gradually transferred from loading-end to free-end, the loading-end slip was larger than the free-end slip at the first three segments.
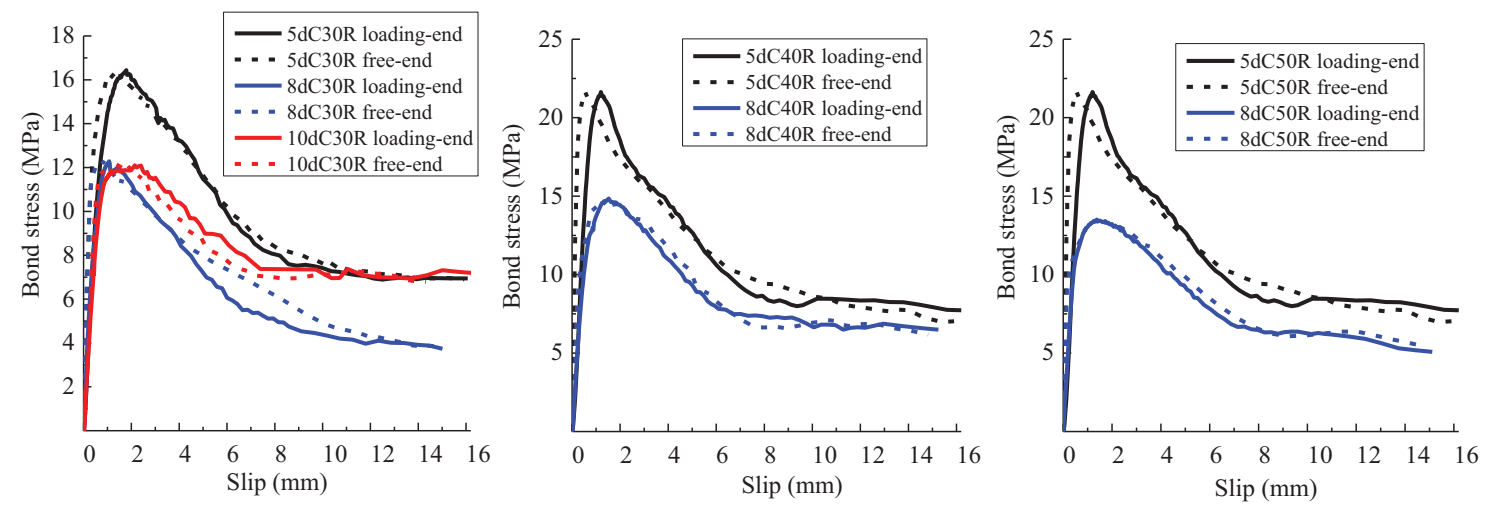

Fig. (5). Bond-slip curve of steel-bar pull-out failure.

\subsection{Concrete Splitting Failure and Bond-slip Curve}

When the bond length of steel bar was shorter than $10 \mathrm{~d}$, specimens without lateral constructional stirrups failed mostly due to the aRAC splitting. The specimens failed suddenly into two or three pieces with splitting sound. Some of them presented as steel bar separated from split concrete, some were still bonded together. A large number of coarse RCA fractured at failure interface due to the accumulated damage interior of the RCA particle, as shown in Fig. (6).

In this study, most aRAC splitting failure took place as the aRAC broke suddenly before steel bar yield, and the bond stress reached the ultimate value. Some aRAC split into two or three blocks after steel bar yield, while the concrete crack continuously extended accompanying the yield of steel-bar. No decline segment was on the bond-slip curve of aRAC splitting failure (Fig. 7). 

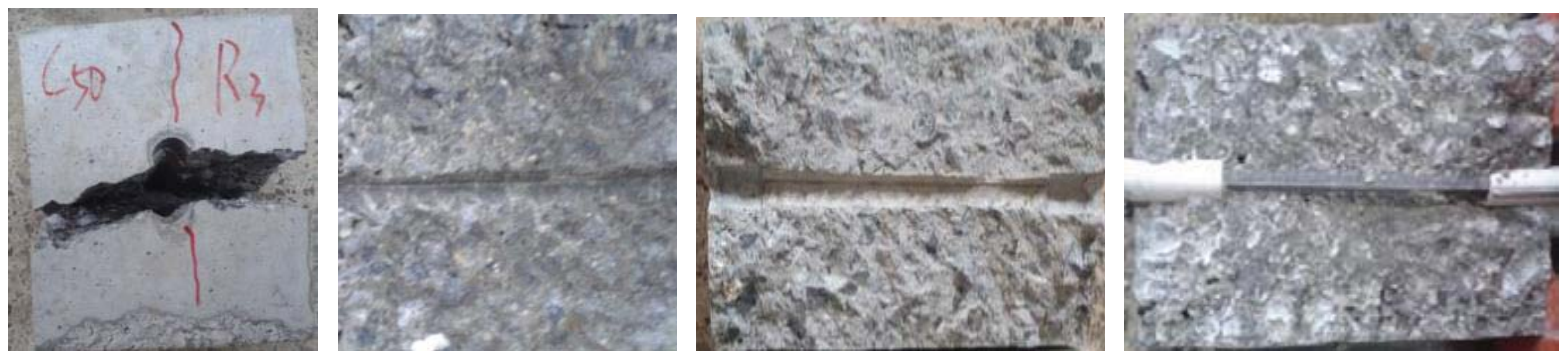

Fig. (6). Concrete splitting failure.
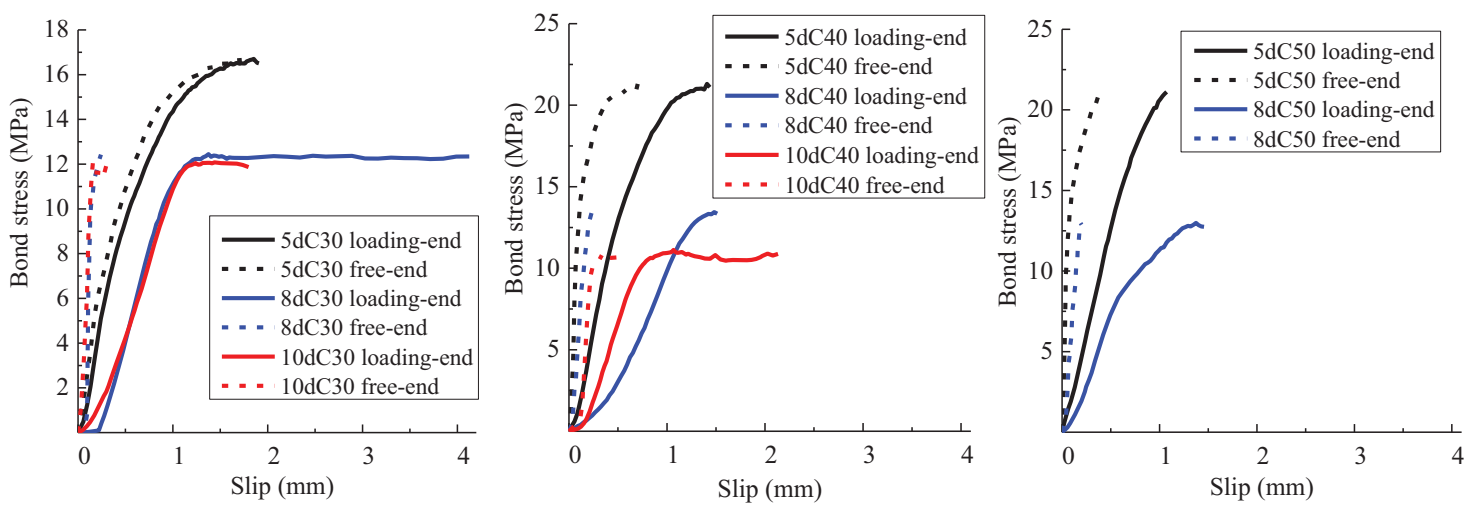

Fig. (7). Bond-slip curve of concrete splitting failure.

\subsection{Steel Bar Yield Failure and Bond-slip Curve}

When the bond length of steel bar was not less than $10 d$, specimens always failed due to the yield of steel bar. The surface of specimen was virgin without crack. In this condition, the bond resistance was higher than the yield force of steel bar. Meanwhile, the lower bond strength and smaller slip values calculated corresponding to this failure, which hold no meanings for the true bond strength between steel bar and aRAC.

The bond-slip curve of loading-end expressed the micro-slip and slip growth while the free-end almost did not slip. The bond strength could not get as that the ultimate pull-out load was the yield force of steel bar (Fig. 8).
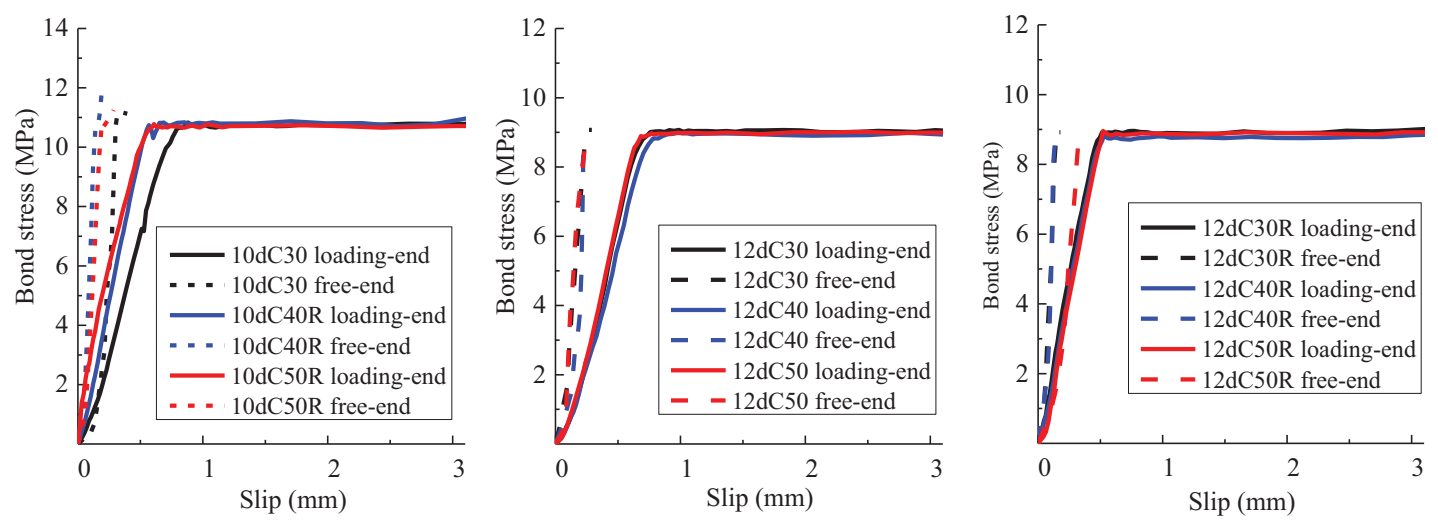

Fig. (8). Bond-slip curve of steel-bar yield failure. 


\section{DISCUSSION}

\subsection{Factors Influencing the Bond Strength}

The maximum bond stress is the bond strength $\left(\tau_{\mathrm{u}}\right)$, and the corresponding slip is marked as $s_{\mathrm{u}}$. Table 6 lists test values of bond strength $\left(\tau_{\mathrm{u}}\right)$ and slips at free-end $\left(s_{\mathrm{f}, \mathrm{u}}\right)$ and loading-end $\left(s_{\mathrm{l}, \mathrm{u}}\right)$. Corresponding to the pull-out of steel bar and concrete splitting, the mean values are computed of the deviation within $20 \%$.

Table 6. Failure mode of specimen and test data of bond strength and slip.

\begin{tabular}{|c|c|c|c|c|c|c|c|}
\hline \multirow[t]{2}{*}{ Specimen group no. } & \multirow[t]{2}{*}{ Failure mode } & \multicolumn{2}{|c|}{$s_{\mathrm{f}, \mathrm{u}}(\mathrm{mm})$} & \multicolumn{2}{|c|}{$s_{1, \mathrm{u}}(\mathrm{mm})$} & \multicolumn{2}{|c|}{$\tau_{\mathrm{u}}(\mathrm{MPa})$} \\
\hline & & test value & mean & test value & mean & test value & mean \\
\hline $5 \mathrm{dC} 30$ & $\mathrm{CS} / \mathrm{CS} / \mathrm{CS}$ & $2.01 / 1.34 / 1.29$ & 1.32 & $1.96 / 1.66 / 1.90$ & 1.78 & $15.35 / 16.28 / 18.49$ & 17.38 \\
\hline $5 \mathrm{dC} 40$ & $\mathrm{CS} / \mathrm{CS} / \mathrm{CS}$ & $0.94 / 0.57 / 0.59$ & 0.58 & $1.67 / 1.27 / 1.29$ & 1.28 & $21.63 / 21.59 / 20.68$ & 21.13 \\
\hline $5 \mathrm{dC} 50$ & $\mathrm{CS} / \mathrm{CS} / \mathrm{CS}$ & $0.61 / 0.56 / 0.31$ & 0.56 & $1.15 / 1.63 / 0.82$ & 1.63 & $20.43 / 21.23 / 21.68$ & 21.23 \\
\hline $5 \mathrm{dC} 30 \mathrm{R}$ & $\mathrm{PO} / \mathrm{PO} / \mathrm{PO}$ & $0.87 / 1.34 / 1.55$ & 1.34 & $1.23 / 1.95 / 2.03$ & 1.95 & $15.31 / 16.55 / 17.46$ & 17.00 \\
\hline $5 \mathrm{dC} 40 \mathrm{R}$ & $\mathrm{PO} / \mathrm{PO} / \mathrm{PO}$ & $0.64 / 0.33 / 0.21$ & 0.33 & $0.90 / 1.23 / 1.23$ & 1.23 & $21.89 / 20.35 / 19.88$ & 20.35 \\
\hline $5 \mathrm{dC} 50 \mathrm{R}$ & $\mathrm{PO} / \mathrm{PO} / \mathrm{PO}$ & $0.59 / 0.05 / 0.48$ & 0.54 & $1.23 / 1.41 / 0.95$ & 1.09 & $21.95 / 21.89 / 21.06$ & 21.56 \\
\hline $8 \mathrm{dC} 30$ & $\mathrm{CSA} / \mathrm{CSA} / \mathrm{CSA}$ & $0.21 / 0.26 / 0.24$ & 0.24 & $1.43 / 1.36 / 0.99$ & 1.26 & $12.54 / 12.43 / 12.36$ & 12.44 \\
\hline $8 \mathrm{dC} 40$ & $\mathrm{CS} / \mathrm{CSA}$ & $0.19 / 0.28$ & 0.24 & $1.62 / 1.36$ & 1.49 & $11.41 / 15.05$ & 13.23 \\
\hline $8 \mathrm{dC} 50$ & $\mathrm{CSA} / \mathrm{CS}$ & $0.17 / 0.21$ & 0.19 & $1.51 / 1.23$ & 1.37 & $14.73 / 11.24$ & 12.99 \\
\hline $8 \mathrm{dC} 30 \mathrm{R}$ & $\mathrm{PO} / \mathrm{PO} / \mathrm{PO}$ & $1.29 / 0.50 / 0.45$ & 0.75 & $1.39 / 0.94 / 0.82$ & 1.05 & $12.14 / 12.64 / 12.11$ & 12.30 \\
\hline $8 \mathrm{dC} 40 \mathrm{R}$ & $\mathrm{PO} / \mathrm{PO} / \mathrm{PO}$ & $0.35 / 1.29 / 1.41$ & 1.01 & $1.36 / 1.23 / 1.98$ & 1.52 & $15.16 / 13.18 / 16.22$ & 14.85 \\
\hline $8 \mathrm{dC} 50 \mathrm{R}$ & $\mathrm{PO} / \mathrm{PO} / \mathrm{PO}$ & $1.41 / 0.75 / 1.39$ & 1.18 & $1.57 / 0.97 / 1.18$ & 1.24 & $13.10 / 13.05 / 13.92$ & 13.35 \\
\hline $10 \mathrm{dC} 30$ & $\mathrm{CS} / \mathrm{CS}$ & $0.17 / 0.14$ & 0.16 & $1.83 / 0.89$ & 1.36 & $10.90 / 12.39$ & 11.65 \\
\hline $10 \mathrm{dC} 40$ & $\mathrm{CS} / \mathrm{CS} / \mathrm{CS}$ & $0.33 / 0.33 / 0.33$ & 0.33 & $0.73 / 0.96 / 1.51$ & 1.07 & $10.81 / 10.89 / 11.66$ & 11.12 \\
\hline 10dC30R & PO & 0.77 & 0.77 & 1.34 & 1.34 & 11.89 & 11.89 \\
\hline
\end{tabular}

Note: CS- concrete splitting, PO-pull out, CSA-concrete splitting after yield of steel-bar

Based on test data in Table 6, Fig. (9) shows the changes of bond strength with aRAC strength. Generally, the increase of aRAC strength has beneficial effect on the bond strength. With the same mechanism of ordinary concrete [46], the compressive strength controls the ability of aRAC in front of the crescent ribs of steel bar under compression, while the tensile strength controls the adhesion bond of steel bar and the splitting resistance of aRAC under lateral pushing force. As the damage degree of aRAC connected with steel bar reduces with the increase of aRAC strength, the bond strength increases slightly for specimens with high aRAC strength [27]. As the lateral constructional stirrup was only to avoid the splitting failure of aRAC, the bond strengths of specimens with or without lateral constructional stirrup had a little difference. However, the lateral constructional stirrup has the function of confinement on the widening of aRAC crack width, the damage degree of aRAC at failure state of specimens without lateral construction stirrup decreases with the increase of bond length. This leads to a less increment of bond strength with aRAC strength for specimens with longer bond length.
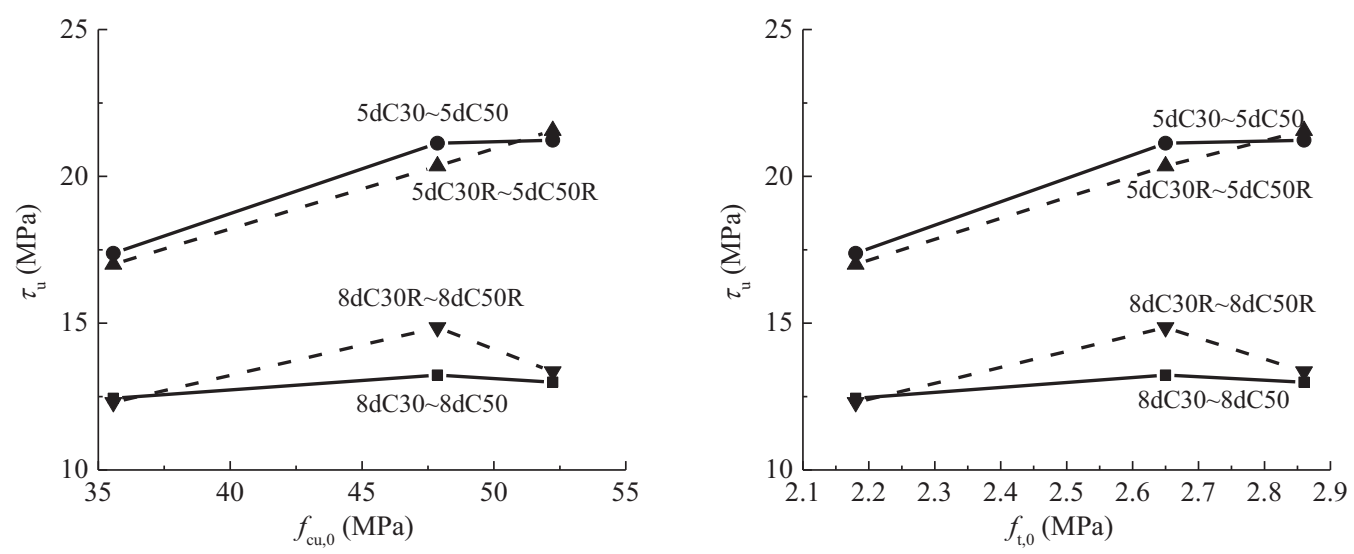

Fig. (9). Variation of bond strength with aRAC strength. 
With the assistance of constructional stirrups, the differential of slips at loading-end and free-end increases with the increasing strength of aRAC, as listed in Table 6, and the descent stage of bond-slip curve becomes craggedness, while the crack was wider during the pull-out of steel bar. With the increasing bond length, the failure changes from pull-out to yield of steel bar, the bond stress reduces because of the non-uniform distribution of bond stress along bond length [28 - 30]. Meanwhile, the slip corresponding to bond strength reduces with the increasing bond length.

\subsection{Modeling of Bond-slip Relationship}

Considering the specimens failed as pull-out of steel bar or aRAC splitting, the bond stress and slip at the initial point of slip segment on the bond-slip curves is defined as $\left(\tau_{\mathrm{s}}, s_{\mathrm{s}}\right)$, and that of internal broken segment is $\left(\tau_{\mathrm{cr}}, s_{\mathrm{cr}}\right)$. Test results are listed in Table 7, which are obtained by the analyses on the slope of bond-slip curves as shown in Figs. (5 and 7). In which $f_{\mathrm{cu}, 0}$ and $f_{\mathrm{t}, 0}$ are the test values of cubic compressive strength and tensile strength of aRAC.

Table 7. Characteristic point data of bond-slip curve.

\begin{tabular}{|c|c|c|c|c|c|c|c|c|}
\hline Specimen group no. & $\begin{array}{c}f_{\text {cu, } 0} \\
(\mathbf{M P a})\end{array}$ & $\begin{array}{c}f_{\mathrm{t,0},} \\
(\mathbf{M P a}) \\
\end{array}$ & $\begin{array}{c}\tau_{\mathrm{s}} \\
(\mathbf{M P a}) \\
\end{array}$ & $\begin{array}{c}\begin{array}{c}S_{\mathrm{s}} \\
(\mathbf{m m})\end{array} \\
\end{array}$ & $\begin{array}{c}\tau_{\text {cr }} \\
\text { (MPa) } \\
\end{array}$ & $\begin{array}{c}S_{\mathrm{cr}} \\
(\mathrm{mm})\end{array}$ & $\begin{array}{c}\tau_{\mathrm{u}} \\
(\mathbf{M P a}) \\
\end{array}$ & $\begin{array}{c}s_{\mathrm{u}} \\
(\mathbf{m m})\end{array}$ \\
\hline $5 \mathrm{dC} 30 \mathrm{R}$ & 35.57 & 2.18 & 2.74 & 0.06 & 13.40 & 0.47 & 17.00 & 1.64 \\
\hline $5 \mathrm{dC} 30$ & 35.57 & 2.18 & 2.76 & 0.10 & 13.48 & 0.42 & 17.38 & 1.55 \\
\hline $5 \mathrm{dC} 40 \mathrm{R}$ & 47.86 & 2.65 & 2.05 & 0.09 & 17.61 & 0.35 & 20.35 & 0.78 \\
\hline $5 \mathrm{dC} 40$ & 47.86 & 2.65 & 3.00 & 0.06 & 18.60 & 0.27 & 21.13 & 0.93 \\
\hline $5 \mathrm{dC} 50 \mathrm{R}$ & 52.23 & 2.86 & 3.03 & 0.06 & 17.92 & 0.22 & 21.56 & 0.82 \\
\hline $5 \mathrm{dC} 50$ & 52.23 & 2.86 & 3.23 & 0.06 & 17.45 & 0.18 & 21.23 & 1.10 \\
\hline $8 \mathrm{dC} 30 \mathrm{R}$ & 35.57 & 2.18 & 2.91 & 0.06 & 11.74 & 0.27 & 12.30 & 0.90 \\
\hline $8 \mathrm{dC} 30$ & 35.57 & 2.18 & 2.09 & 0.05 & 11.38 & 0.13 & 12.44 & 0.75 \\
\hline $8 \mathrm{dC} 40 \mathrm{R}$ & 47.86 & 2.65 & 1.86 & 0.08 & 10.30 & 0.26 & 14.85 & 1.27 \\
\hline $8 \mathrm{dC} 40$ & 47.86 & 2.65 & 2.17 & 0.05 & 12.52 & 0.19 & 13.23 & 0.87 \\
\hline $8 \mathrm{dC} 50 \mathrm{R}$ & 52.23 & 2.86 & 2.50 & 0.07 & 10.23 & 0.26 & 13.35 & 1.21 \\
\hline $8 \mathrm{dC} 50$ & 52.23 & 2.86 & 2.78 & 0.05 & 10.21 & 0.14 & 12.99 & 0.78 \\
\hline 10dC30R & 35.57 & 2.18 & 1.95 & 0.06 & 9.66 & 0.20 & 11.89 & 1.06 \\
\hline 10dC30 & 35.57 & 2.18 & 1.90 & 0.05 & 9.77 & 0.16 & 11.65 & 0.76 \\
\hline $10 \mathrm{dC} 40$ & 47.86 & 2.65 & 2.03 & 0.05 & 9.88 & 0.12 & 11.12 & 0.70 \\
\hline
\end{tabular}

As mentioned above, the lateral constructional stirrups confined the extending of splitting cracks of aRAC, and maintained the bond between steel bar and aRAC with a large slip. This increased the ductility of bond after splitting crack appeared at surface of specimens. Considering that the rising segments of bond-slip curves of specimens were almost overlapped without affected by the lateral constructional stirrups, test data of bond stress and slip at key points are statistically analyzed for the specimens with the same bond length of steel bar; the results are listed in Table $\mathbf{8}$. $\mu$ is the average while $\delta$ represents the variance.

Table 8. Statistical analysis of characteristic values at key points.

\begin{tabular}{|c|c|c|c|c|c|c|c|c|c|c|c|c|}
\hline \multirow{2}{*}{$\begin{array}{l}\text { Bond length } \\
\text { of specimen }\end{array}$} & \multicolumn{2}{|c|}{$\tau_{\mathrm{s}} / f_{\mathrm{t}, 0}$} & \multicolumn{2}{|c|}{$\boldsymbol{\tau}_{\mathrm{cr}} / \boldsymbol{f}_{\mathrm{t}, 0}$} & \multicolumn{2}{|c|}{$\tau_{\mathrm{u}} / f_{\mathrm{t}, 0}$} & \multicolumn{2}{|c|}{$s_{\mathrm{s}} / s_{\mathrm{u}}$} & \multicolumn{2}{|c|}{$S_{\mathrm{cr}} / s_{\mathrm{u}}$} & \multicolumn{2}{|c|}{$s_{\mathrm{u}}$} \\
\hline & $\mu$ & $\delta$ & $\mu$ & $\delta$ & $\mu$ & $\delta$ & $\mu$ & $\delta$ & $M$ & $\delta$ & $\mu$ & $\Delta$ \\
\hline $5 d$ & 1.10 & 0.163 & 6.39 & 0.057 & 7.73 & 0.029 & 0.068 & 0.387 & 0.29 & 0.318 & 1.14 & 0.328 \\
\hline $8 d$ & 0.94 & 0.228 & 4.39 & 0.187 & 5.19 & 0.101 & 0.063 & 0.065 & 0.22 & 0.211 & 0.96 & 0.230 \\
\hline $10 d$ & 0.84 & 0.081 & 4.21 & 0.099 & 4.99 & 0.139 & 0.065 & 0.115 & 0.19 & 0.109 & 0.84 & 0.229 \\
\hline
\end{tabular}

Based on the statistical average values listed in Table 8, the relationships of $\tau_{\mathrm{s}} / f_{\mathrm{t}, 0}, \tau_{\mathrm{cr}} / f_{\mathrm{t}, 0}$ and $\tau_{\mathrm{u}} / f_{\mathrm{t}, 0}$ with $l_{\mathrm{a}} / d$ can be represented as linear shown in Fig. (10), as stated that the stresses and slips decreased with the increasing bond length. Compared to the values of bond-slip curve of steel bar with $5 d$ bond length in manufactured sand concrete [46], the values of $\tau_{\mathrm{s}} / f_{\mathrm{t}, 0}, \tau_{\mathrm{cr}} / f_{\mathrm{t}, 0}$ and $\tau_{\mathrm{u}} / f_{\mathrm{t}, 0}$ presented in Table 8 are larger while those of $s_{\mathrm{s}}, s_{\mathrm{cr}}$ and $s_{\mathrm{u}}$ are lower. This presents a better bond property of deformed steel bar to aRAC, due to the enhancement of the secondary hydration of cement grains composited in fine RCA on the interface between deformed steel bar and aRAC [20,21]. Similar test results have been reported for the bond strength between deformed steel bar and RAC [26, 31]. 


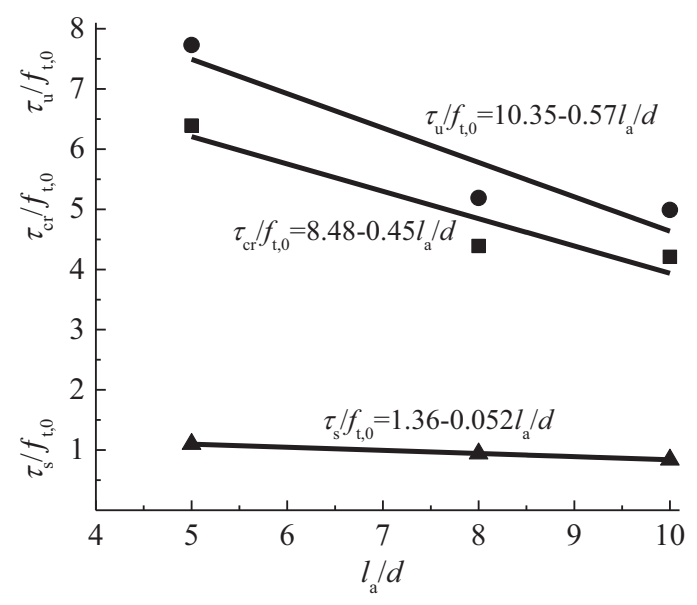

Fig. (10). Relationship of bond stresses at key points with relative bond length.

Based on the study of bond-slip relationship between deformed steel bar and manufactured sand concrete [46], the bond-slip relationship of deformed steel bar to aRAC can be calculated by least squares approach, and expressed as the composition of micro-slip, slip, internal splitting-broken and decline segments,

$$
\begin{aligned}
& \tau=\tau_{\mathrm{s}} \sqrt[4]{\frac{s}{s_{\mathrm{s}}}} \quad\left(0<s \leq s_{\mathrm{s}}\right) \\
& \tau=\frac{\tau_{\mathrm{cr}}\left(\sqrt[4]{s}-\sqrt[4]{s_{\mathrm{s}}}\right)-\tau_{\mathrm{s}}\left(\sqrt[4]{s}-\sqrt[4]{s_{\mathrm{cr}}}\right)}{\sqrt[4]{s_{\mathrm{cr}}}-\sqrt[4]{s_{\mathrm{s}}}} \quad\left(s_{\mathrm{s}}<s \leq s_{\mathrm{cr}}\right) \\
& \tau=\tau_{\mathrm{u}}\left[1-\frac{\left(s-s_{\mathrm{u}}\right)^{2}}{\left(s_{\mathrm{u}}-s_{\mathrm{cr}}\right)^{2}}\left(1-\frac{\tau_{\mathrm{cr}}}{\tau_{\mathrm{u}}}\right)\right] \quad\left(s_{\mathrm{cr}}<s \leq s_{\mathrm{u}}\right) \\
& \tau=\frac{\tau_{\mathrm{u}}}{0.1\left[f_{\mathrm{t}}\left(1-\frac{s_{\mathrm{u}}}{s}\right)\right]^{2 \alpha_{\mathrm{sr}}}+1} \quad\left(s_{\mathrm{u}}<s \leq d\right)
\end{aligned}
$$

where, $f_{\mathrm{t}}$ is the tensile strength of aRAC, $\alpha_{\mathrm{sr}}$ is the influencing coefficient of RCA, and all other terms are as previously described.

In this study, $\alpha_{\mathrm{sr}}=1.15$. The friction-slip of steel bar took place when the slip was over 1.5 times of the distance of crescent ribs, and the distance is about $0.7 d$, the maximum slip is taken as $1.5 \times 0.7 d \approx d$.

Combined with the averages characteristic values at key points listed in Table $\mathbf{8}$, the comparisons of test and calculated bond-slip curves are shown in Fig. (11), in which the vertical axis $\left(\tau / f_{t}\right)$ is the bond stress relative to tensile strength of aRAC, the longitudinal axis $\left(s / s_{\mathrm{u}}\right)$ is the relative slip to that corresponding to bond strength. For the decline segment calculated by formula (5), considering the range of test tensile strength of aRAC in this study, the tensile strength of aRAC $\left(f_{\mathrm{t}}\right)$ is taken as $2.5 \mathrm{MPa}$ and $3.5 \mathrm{MPa}$, respectively. Generally, the test and computed curves agree well in trends with some difference in decline segment. 

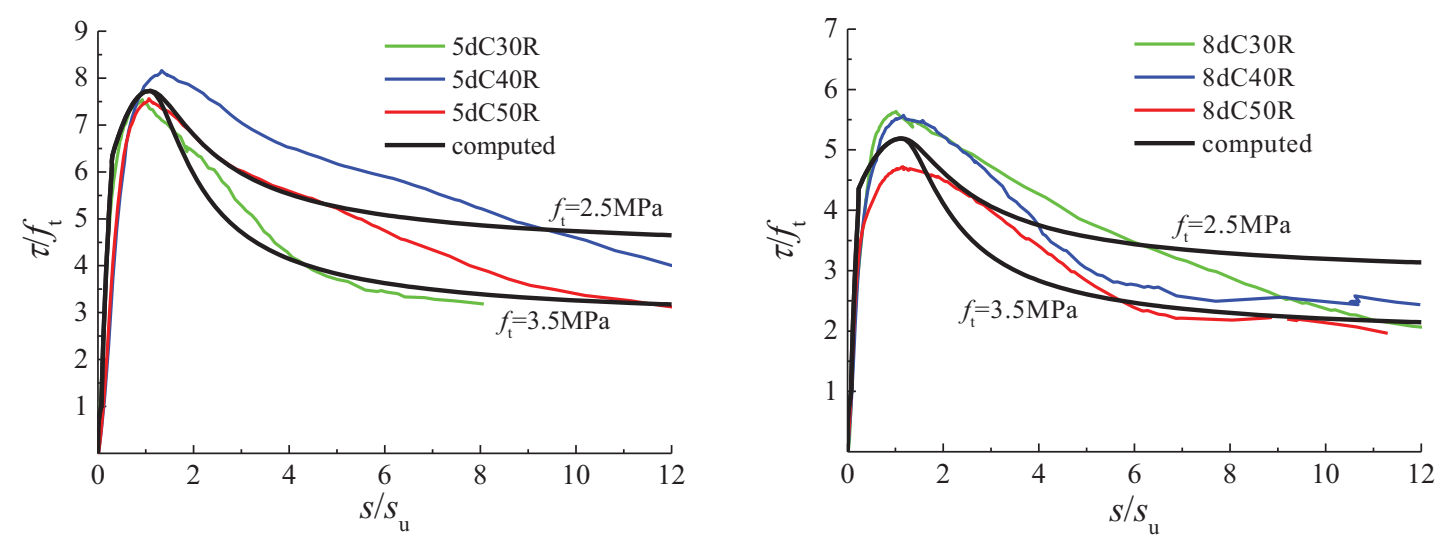

Fig. (11). Comparison of bond-slip curves of specimens.

\section{CONCLUSION}

Full-recycled-aggregate concrete (aRAC) was innovated to reach the target of fully reusing the crushed products of waste concrete from demolished concrete structures. Before applying reinforced concrete structures, the reliability of the aRAC bond performance with steel bar should be ensured. As there is lack of study on this topic, findings of research work presented in this paper have added to the current knowledge. The following conclusions are based on the tests and analysis of 24 groups of specimens in this paper:

(1) The bond behaviors between deformed steel bar and aRAC were reliable in conditions of reasonable bond length of steel bar, which presented the yield of steel bar under pull-out force. When the bond length of steel bar was shorter than $10 d$, failure of steel bar pulled out of aRAC took place in specimens with lateral confinement of constructional stirrups, while failure of aRAC splitting in those without constructional stirrups. The bond strength increased with the increase of aRAC strength, and decreased with the increase of bond length.

(2) As the constructional stirrups were only to avoid the brittle failure of aRAC splitting along the deformed steel bar, the decline stage of bond-slip curve was obtained from specimen failed in pull-out of steel bar. Based on the test bond-slip curves, the bond stress and slip at key points are determined and statistically analyzed in relation with the tensile strength of aRAC and the bond length of steel bar. It shows a higher bond property between deformed steel bar and aRAC, compared to that between deformed steel bar and ordinary concrete.

(3) The formulas expressing the bond-slip relationship between deformed steel bar and aRAC are proposed, determined by the characteristic values at key points in relation with aRAC tensile strength and bond length, and the influence of RCA on decline segment. The test and calculated results fit well.

\section{CONSENT FOR PUBLICATION}

Not applicable.

\section{CONFLICT OF INTEREST}

The authors declare no conflict of interest, financial or otherwise.

\section{ACKNOWLEDGEMENTS}

The study was financially supported by the Science and Technology Innovation Team of Eco-building Material and Structural Engineering in the University of Henan Province, China (13IRTSTHN002), the Fund of Leading Personnel of Science and Technology of Zhengzhou City, China (096SYJH23105), and the Key Research Project in University of Henan Province, China (16A560023).

\section{REFERENCES}

[1] GB/T 25177. Recycled Coarse Aggregate for Concrete, China Building Industry Press: Beijing, 2010.

[2] GB/T 25176. Recycled Fine Aggregate for Concrete and Mortar, China Building Industry Press: Beijing, 2010. 
[3] X.P. Li, "Recycling and reuse of waste concrete in China Part I. material behaviour of recycled aggregate concrete", Resour. Conserv. Recycling, no. 53, pp. 36-44, 2008. [http://dx.doi.org/10.1016/j.resconrec.2008.09.006]

[4] J.Z. Xiao, W.G. Li, Y.H. Fan, and X. Huang, "An overview of study on recycled aggregate concrete in China (1996-2011)", Constr. Build. Mater., no. 31, pp. 364-383, 2012. [http://dx.doi.org/10.1016/j.conbuildmat.2011.12.074]

[5] S. Nagataki, A. Gokce, T. Saeki, and M. Hisada, "Assessment of recycling process induced damage sensitivity of recycled concrete aggregate", Cement Concr. Res., vol. 34, no. 6, pp. 965-971, 2004.

[http://dx.doi.org/10.1016/j.cemconres.2003.11.008]

[6] W.Y. Vivian Tam, X.P. Gao, and C.M. Tam, "Microstructural analysis of recycled aggregate concrete produced from two-stage mixing approach", Cement Concr. Res., vol. 35, no. 6, pp. 1195-1203, 2005. [http://dx.doi.org/10.1016/j.cemconres.2004.10.025]

[7] D.S. Seo, and H.B. Choi, "Effects of the old cement mortar attached to the recycled aggregate surface on the bond characteristics between aggregate and cement mortar", Constr. Build. Mater., no. 59, pp. 72-79, 2014. [http://dx.doi.org/10.1016/j.conbuildmat.2014.02.047]

[8] S. Lotfi, M. Eggimann, E. Wagner, R. Mroz, and J. Deja, "Performance of recycled aggregate concrete based on a new concrete recycling technology", Constr. Build. Mater., no. 95, pp. 243-256, 2015. [http://dx.doi.org/10.1016/j.conbuildmat.2015.07.021]

[9] A. Ajdukiewicz, and A. Kliszczewicz, "Influence of recycled aggregates on mechanical properties of HS/HPC", Cement Concr. Compos., vol. 24, no. 2, pp. 269-279, 2002. [http://dx.doi.org/10.1016/S0958-9465(01)00012-9]

[10] K. Rahal, "Mechanical properties of concrete with recycled coarse aggregate", Build. Environ., vol. 42, no. 1, pp. 407-415, 2007. [http://dx.doi.org/10.1016/j.buildenv.2005.07.033]

[11] A. Behnood, J. Olek, and M. A. Glinicki, "Predicting modulus elasticity of recycled aggregate concrete using M5' model tree algorithm", Constr. Build. Mater., no. 94, pp. 137-147, 2015. [http://dx.doi.org/10.1016/j.conbuildmat.2015.06.055]

[12] JGJ 55, Specification for mix proportion design of ordinary concrete, China Building Industry Press: Beijing, 2011.

[13] F.L. Li, J. Li, S. Chen, and W.J. Zhao, "Experiment of basic mechanical properties of concrete mixed with composite aggregate", Adv. Mat. Res., vol. 168-170,pp. 2178-2181, 2011 [http://dx.doi.org/10.4028/www.scientific.net/AMR.168-170.2178]

[14] S.B. Zhao, Q. Guo, G.X. Li, Y.F. Su, and W.J. Shao, "Basic mechanical properties of concrete with machine-made sand and recycled coarse aggregate", Appl. Mech. Mater., vol. 357-360, pp. 1102-1105, 2013. [http://dx.doi.org/10.4028/www.scientific.net/AMM.357-360.1102]

[15] S. Kou, and C. Poon, "Effect of the quality of parent concrete on the properties of high performance recycled aggregate concrete", Constr. Build. Mater., no. 77, pp. 501-508, 2015.

[http://dx.doi.org/10.1016/j.conbuildmat.2014.12.035]

[16] L. Butler, J.S. West, and S.L. Tighe, "Effect of recycled concrete coarse aggregate from multiple sources on the hardened properties of concrete with equivalent compressive strength", Constr. Build. Mater., no. 47, pp. 1292-1301, 2013. [http://dx.doi.org/10.1016/j.conbuildmat.2013.05.074]

[17] A.A. Elhakam, A.E. Mohamed, and E. Awad, "Influence of self-healing, mixing method and adding silica fume on mechanical properties of recycled aggregates concrete", Constr. Build. Mater., no. 35, pp. 421-427, 2012. [http://dx.doi.org/10.1016/j.conbuildmat.2012.04.013]

[18] A.S. Brand, J.R. Roesler, and A. Salas, "Initial moisture and mixing effects on higher quality recycled coarse aggregate concrete", Constr. Build. Mater., no. 26, pp. 565-573, 2012.

[19] Y. Liang, Z. Ye, F. Vernerey, and Y. Xi, "Development of processing methods to improve strength of concrete with $100 \%$ recycled coarse aggregate", J. Mater. Civil Eng., vol. 27, no. 5, p. 04014163(9), 2015. [http://dx.doi.org/10.1061/(ASCE)MT.1943-5533.0000909]

[20] L. Evangelista, M. Guedes, J. de Brito, A.C. Ferro, and M.F. Pereira, "Physical, chemical and mineralogical properties of fine recycled aggregates made from concrete waste", Constr. Build. Mater., no. 86, pp. 178-188, 2015. [http://dx.doi.org/10.1016/j.conbuildmat.2015.03.112]

[21] L. Evangelista, and J. De Brito, "Mechanical behaviour of concrete made with fine recycled concrete aggregates", Cement Concr. Compos., vol. 29 , no. 5, pp. 397-401, 2007. [http://dx.doi.org/10.1016/j.cemconcomp.2006.12.004]

[22] X.K. Li, Q. Guo, S.B. Zhao, G.X. Li, and Y.F. Su, "Experimental study on mix design of full-recycled-aggregate concrete", J. North China Univer. Water Res. Elect. Power, vol. 34, no. 4, pp. 53-56, 2013.

[23] C.Y. Li, G.X. Li, W.J. Shao, Q. Guo, and R. Liu, "Shear-crack behaviors of reinforced full-recycled aggregate concrete beams", Appl. Mech. Mater., vol. 438-439, pp. 794-799, 2013. 
[http://dx.doi.org/10.4028/www.scientific.net/AMM.438-439.794]

[24] S-W. Kim, and H-D. Yun, "Evaluation of the bond behavior of steel reinforcing bars in recycled fine aggregate concrete", Cement Concr. Compos., no. 46, pp. 8-18, 2014.

[http://dx.doi.org/10.1016/j.cemconcomp.2013.10.013]

[25] L. Butler, J.S. West, and S.L. Tighe, "The effect of recycled concrete aggregate properties on the bond strength between RCA concrete and steel reinforcement", Cement Concr. Res., vol. 41, no. 10, pp. 1037-1049, 2011. [http://dx.doi.org/10.1016/j.cemconres.2011.06.004]

[26] Q. Hu, W.W. Chen, and C.Y. Zhou, "Experimental study on bonding properties of recycled concrete", J. Harbin Institute Tech., vol. 42, no. 12, pp. 1849-1854, 2010.

[27] B. Wang, G.L. Bai, H.J. Dai, and S.H. Wu, "Experimental and mechanical analysis on bond-slip performance between recycled concrete and rebar", Eng. Mechanics, vol. 30, no. 10, pp. 54-64, 2013.

[28] P.C. Li, Y.K. Peng, F. Li, and H. Wu, "Effects of coarse recycled aggregate on the bond behavior between concrete and rebar", J. Civil, Architect. Environ. Eng., vol. 38, no. suppl, pp. 6-12, 2016.

[29] H.F. Yang, Z.H. Deng, X.L. Li, and Y.F. Hu, "Experimental study on bond-slip relationship between recycled concrete and steel bar", J. Build. Mater., vol. 16, no. 3, pp. 429-436, 2013.

[http://dx.doi.org/10.3969/j.issn.1007-9629.2013.03.009]

[30] C.X. Wang, J. Wu, and Z.H. Chen, "Experimental research on bond behavior between recycled concrete and rebar", China Civil Eng. J., vol. 46, no. suppl. 2, pp. 225-231, 2013. [http://dx.doi.org/10.15951/j.tmgcxb.2013.s2.039]

[31] S. H. Kim, S. H. Lee, Y. T. Lee, and S. U. Hong, "Bond between high strength concrete with recycled coarse aggregate and reinforcing bars", Mater. Res. Innovations, vol. 18, no. suppl 2, pp. 278-285, 2014 [http://dx.doi.org/10.1179/1432891714Z.000000000417]

[32] M.J. Prince, and B. Singh, "Bond behaviour of deformed steel bars embedded in recycled aggregate concrete", Constr. Build. Mater., no. 49, pp. 852-862, 2013. [http://dx.doi.org/10.1016/j.conbuildmat.2013.08.031]

[33] X.Z. An, C. Yi, Y. Liu, and J.T. Zhang, "Study on bond behavior between recycled aggregate concrete and steel bar", J. Hebei Univer. Tech., vol. 27, no. 3, pp. 1-4, 2010 .

[34] J.Z. Xiao, P.S. Li, and W. Qin, "Study on bond-slip between recycled concrete and rebars", J. Tongji Univer. Nat. Sci., vol. 34, no. 1, pp. 13-16, 2014.

[35] J. Xiao, and H. Falkner, "Bond behaviour between recycled aggregate concrete and steel rebars", Constr. Build. Mater., no. 21, pp. 395-401, 2007.

[http://dx.doi.org/10.1016/j.conbuildmat.2005.08.008]

[36] M. Breccolotti, and A.L. Materazzi, "Structural reliability of bonding between steel rebars and recycled aggregate concrete", Constr. Build. Mater., no. 47, pp. 927-934, 2013 [http://dx.doi.org/10.1016/j.conbuildmat.2013.05.017]

[37] M.J. Prince, and B. Singh, "Bond behaviour between recycled aggregate concrete and deformed steel bars", Mater. Struct., no. 47, pp. 503-516, 2014.

[http://dx.doi.org/10.1617/s11527-013-0075-8]

[38] Y.F. Xu, W.M. Sun, and Z.G. Guo, "Experimental study on bond property between recycled concrete and rebar", Special Structures, vol. 29, no. 3, pp. 81-84, 2013.

[39] G. Fathifazl, A.G. Razaqpur, O.B. Isgor, A. Abbas, B. Fournier, and S. Foo, "Bond performance of deformed steel bars in concrete produced with coarse recycled concrete aggregate", Can. J. Civ. Eng., no. 39, pp. 128-139, 2012. [http://dx.doi.org/10.1139/111-120]

[40] J. Zhao, and G.W. Wang, "Test and study on bonding properties of recycled aggregate concrete with recycled aggregate rate", Sichuan Build. Sci., vol. 40, no. 2, pp. 225-228, 2014.

[41] L. Butler, J.S. West, and S.L. Tighe, "Bond of Reinforcement in Concrete Incorporating Recycled Concrete Aggregates", J. Struct. Eng., vol. 141, no. 3, p. B4014001, 2015. [http://dx.doi.org/10.1061/(ASCE)ST.1943-541X.0000928]

[42] S. Seara-Paz, B. González-Fonteboa, J. Eiras-López, and M.F. Herrador, "Bond behavior between steel reinforcement and recycled concrete", Mater. Struct., no. 47, pp. 323-334, 2014. [http://dx.doi.org/10.1617/s11527-013-0063-z]

[43] S-W. Kim, and H-D. Yun, "Influence of recycled coarse aggregates on the bond behavior of deformed bars in concrete", Eng. Struct., no. 48, pp. 133-143, 2013.

[http://dx.doi.org/10.1016/j.engstruct.2012.10.009]

[44] GB 50152, Standard of Test Methods for Concrete Structures, China Building Industry Press: Beijing, 2012.

[45] GB/T 50081, Standard for test method of mechanical properties on ordinary concrete, China Building Industry Press: Beijing, 2012. 
[46] S.B. Zhao, X.X. Ding, C.M. Li, and C.Y. Li, "Experimental study on bond properties between deformed steel bar and concrete with machinemade sand", J. Build. Mater., vol. 12, no. 3, pp. 191-196, 2013.

[http://dx.doi.org/10.1016/j.conbuildmat.2013.01.032]

\section{(C) 2017 Li et al.}

This is an open access article distributed under the terms of the Creative Commons Attribution 4.0 International Public License (CC-BY 4.0), a copy of which is available at: https://creativecommons.org/licenses/by/4.0/legalcode. This license permits unrestricted use, distribution, and reproduction in any medium, provided the original author and source are credited. 